\title{
Participation of Public in Panchayati Raj Institutions of East Siang District, Arunachal Pradesh
}

\author{
Kamin Modi ${ }^{1}$, Dr. Tabang Mibang ${ }^{2}$, Dr. Philip Modi ${ }^{3 *}$ \\ ${ }^{1}$ Phd Research Scholar, Department of Political Science, Rajiv Gandhi University, Itanagar, Arunachal Pradesh, India \\ ${ }^{2}$ Assistant Professor, Department of Political Science, Rajiv Gandhi University, Itanagar, Arunachal Pradesh, India \\ ${ }^{3}$ Assistant Professor, Department of Commerce, Rajiv Gandhi University, Itanagar, Arunachal Pradesh, India
}

Article History
Received: 21.02 .2021
Accepted: 04.03 .2021
Published: 15.03 .2021
Journal homepage:
https://www.easpublisher.com

Abstract: The essence and success of Panchayati Raj Institutions lies on the participation of the public in various activities of Panchayati Raj Institutions of a particular area. In the present study, involvement of the villagers in Panchayati Raj activities, consultation of the villagers in planning a scheme, consideration of the villagers for proposal of schemes and participation of the villagers in Panchayat Meetings of East Siang District have been analysed. The study found a contradiction of view point with regard to participation of villagers. Quite a good number of respondents hold the view that, they have not actively participated because they were not encouraged by the panchayat members. On the other hand, panchayat members consider that, they had never been an obstacle to people's participation rather, they encourage them to participate in the developmental programmes initiated by them. Infact, the initiative of common villagers in their individual or collective capacity is equally required for the effective implementation of any developmental programmes. Hence, awareness campaign such as workshop, demonstration, seminar, symposium, etc. are to be conducted in the remote rural areas to make full participation of the people in the developmental programmes. With this background, the present study makes an attempt to highlight Rural Development through Panchayat Raj Institutions. Further, it makes an attempt to examine the Participation of Public in Panchayati Raj Institutions in East Siang District of Arunachal Pradesh.

Keywords: Arunachal Pradesh, East Siang, Panchayati Raj Institutions and Participation.

Copyright (C) 2021 The Author(s): This is an open-access article distributed under the terms of the Creative Commons Attribution 4.0 International License (CC BY-NC 4.0) which permits unrestricted use, distribution, and reproduction in any medium for non-commercial use provided the original author and source are credited.

\section{INTRODUCTION}

The state of Arunachal Pradesh like other states also has undergone a drastic change in terms of grass root politics and development after the introduction of Panchayati Raj Institutions [1]. One of the most significant developments after independence was the introduction of Panchayati Raj Institutions in the state. It has connected the tribal politics to the mainland Indian politics. Like other states in India, political evolution started in Arunachal Pradesh too [2]. Before the implementation of Panchayati Raj Institutions, the social and political affairs of the tribes were regulated through traditional self-governing institutions, called as village councils. Panchayati Raj Institutions is an age old Indian indigenous politicoadministrative institution for village autonomy and development in mainland India, but it was absent in this tribal area, instead they were guided by village councils. To ensure proper democratic decentralisation in the state, the government of India passed the North East Frontier Agency (NEFA) Panchayati Raj Regulation, 1967 on the recommendation of Daying Ering committee report and Panchayati Raj system was implemented in 1969 in the state [3].

The Panchayati Raj Institutions in Arunachal Pradesh will provide a sound basis for political and economic growth of the people of the area. Secondly, it will provide a workable medium through which the rural people would be able to express themselves on various problems of the area and also evolved an integral community approach for solutions of problems that concerns the entire agency [4]. Participation is the structural aspect of Panchayati Raj as rising tribal participation in the Panchayati Raj is apparent with the presence of larger number of people from tribal communities in the various offices of the Panchayati Raj. Being statutory in character and having public fund at their disposal for developmental activities, the statutory panchayat somehow or other can now overcome the challenges of the traditional panchayat officials in its early years. Being capable of rendering certain positive services in the field of material benefit to the tribal are the objectives of statutory panchayats by securing the cooperation of the public [5]. The 
degree of this cooperation and participation needs to increase slowly and gradually, for its effective performance. Panchayat should be able to make people participate and feel that the statutory panchayat is effective and popular due to its manifold development activities. So, the essence and success of Panchayati Raj Institutions lies on the participation of the public in various activities of Panchayati Raj Institutions of a particular area [6].

\section{OBJECTIVES OF THE STUDY}

The paper makes an attempt to:

i. Provide an overview of Rural Development through Panchayat Raj Institutions.

ii. Examine the Participation of Public in Panchayati Raj Institutions in East Siang District of Arunachal Pradesh.

\section{Research Methodology \\ Research Methods and Tools}

The study applies Historico-Analytical method to understand both the historical background and the role of Panchayati Raj institutions in Arunachal Pradesh. The data for the study had been drawn both from primary and secondary sources. The primary data was collected through Field Survey by visiting the study area using interview schedule cum questionnaire. For the secondary sources, study depends on various related documents, official acts, reports and records of Panchayat office collected from the records maintained by various institutions of central, state and local selfgovernment agencies such as Panchayat office, SIRD (State Institute of Rural Development), District Rural Development Agency (DRDA), Block Development
Office (BDO), District Census Handbook (DCH), and the Panchayati Raj Institution (PRI) Cell of various Blocks. Both published and unpublished works are also used as secondary sources of data wherever possible. The data were analysed using a simple percentage computation. The study was carried out by visiting panchayat offices at state, district and gram panchayat level. Panchayat leaders of different blocks of the districts were interviewed. The interview schedule cum questionnaire has been designed in English for sake of convenience and translated into local language wherever needed. The extensive Field Notes of the discussions with panchayat members, local intellectuals and beneficiaries of different rural development schemes has been used to supplement the primary data.

\section{Sampling Methods and Size}

The study has a sample size of 400 respondents covering all the Panchayat blocks of the District. The total respondents were classified into two categories viz. Panchayati Raj Institutions Member and Non-Panchayati Raj Institution Members (common public). The panchayat member constitutes of 90 respondents and non-panchayat member (common public) constitutes of 300 respondents. Also, 10 respondents comprised of Panchayat Officials who have been selected randomly. The sample distribution is shown in Table-1. To avail the required data for the study two sets of open ended questionnaire cum interview schedule were prepared for both panchayat members and non-panchayat members separately. For non-panchayat members, the data were collected randomly, 100 respondents each from three divisions viz, Mebo, Pasighat and Ruksin.

Table-1: Distribution of Samples

\begin{tabular}{|l|l|l|}
\hline Panchayat Members (PM) & Non-Panchayat Members (NPM) & Panchayat Officials (PO) \\
\hline 90 & 300 & 10 \\
\hline
\end{tabular}

\section{Universe of the Study}

The universe of the study constitutes Panchayati Raj Institutions of East Siang District of Arunachal Pradesh. The universe of the study is East Siang district. Earlier the district comprised of four administrative divisions namely Pasighat, Mebo, Ruksin and Nari Sub-Division, in the year 2018 Nari Sub-Division was curved out from East Siang district and merged to Lower Siang district. At present East Siang district comprises of three administrative divisions namely, Pasighat division, Mebo division, and Ruksin division with 16 Zilla Parishad Members (ZPM), 156 Anchal Samiti Members (ASM) and 578 Gram Panchayat Members (GPM) segments respectively. The Administrative Status of the Study District is presented in Table-2. 
Table-2: Administrative Status of East Siang District

\begin{tabular}{|l|l|l|l|l|}
\hline Sl. No & Sub-Division & Circle & Year of opening & Ranks of officer \\
\hline 1. & Pasighat & 1. Pasighat & 1911 & Deputy Commissioner ( D.C) Circle Officer ( C.O) \\
& Sub-Division & 2. Yagrung & 2013 & \\
\hline 2. & Mebo & 1. Mebo & 1952 & Additional Deputy Commissioner (D.C) \\
& Sub-Division & 2.Namsing & 2009 & Circle Officer ( C.O) \\
\hline 3. & Ruksin & 1.Ruksin & 1952 & Additional Deputy Commissioner (D.C) \\
& Sub-Division & 2.Billat & 1990 & Circle Officer (C.O) \\
& & 3.Sille-Oyan & 1990 & Circle Officer ( C.O) \\
\hline 4. & Nari & 1.Nari & 1970 & Additional Deputy Commissioner (D.C) \\
& Sub-Division & 2.Koyu & 1990 & Extra Assistant Commissioner (E.A.C) \\
& & 3.New Seren & 1997 & Circle Officer (C.O) \\
& & 4.Kora & 1997 & Circle Officer (C.O) \\
\hline
\end{tabular}

Source: Statistical Handbook, East Siang District, 2016-17

\section{ANALYSIS AND INTERPRETATION OF DATA}

There are various means which drive people's participation in developmental activities. Developmental participation may be described as any voluntary act to influence public policy. It may be as simple as casting a ballot or it may mean running for office; it may be intended to influence the broad outlines of policy making, or it may be very specific. In our daily life there can be various situations where we may be a part of political participation like taking part in group discussion, watching news, casting vote, involvement in political and developmental activities, supporting an issue and like many other situations where we may directly or indirectly become the part of developmental participation. But intensity of developmental participation may vary from individual to individual and from place to place. The intensity of developmental participation depends on several factors, but in rural areas it is solely dependent on the panchayat institutions.

The concept of the study is based on rural development and Panchayati Raj institutions which are concerned with grass root level involvement and participation. It is because of the fact that, the entire system of grass root development needs decentralisation of power, finance, resources and full participation of the local people in the developmental programmes to achieve the desired objectives. The importance of people's participation lies in view of long term effects of the process of modernisation. Therefore, a planned intervention in this process is the sine qua non of integrated development in rural areas.

So, Panchayati Raj Institution is the simplest form of institution which ensures developmental participation at lowest level. It provides a peaceful mechanism for participation of people in the developmental activities in their locality. One of the most common form of participation can be a person tries to persuade a friend or relatives or any other person to attends a rally or meetings related to rural development in their locality. Intensity of participation may vary from individual to individual and from place to place. The intensity of participation depends on several factors. Therefore, attempt has been made to understand the participation of villagers in panchayat institutions in the present study.

Table-3: Participation of Villagers

\begin{tabular}{|l|l|l|l|l|}
\hline \multirow{2}{*}{$\begin{array}{l}\text { Panchayat } \\
\text { Division }\end{array}$} & \multicolumn{3}{|l|}{ Do PRIs encourage popular participation of villagers } & \multirow{2}{*}{ Total } \\
\cline { 2 - 4 } Mebo & Yes & No & Don't Know & \\
& 64 & 19 & 17 & 100 \\
& $64.0 \%$ & $19.0 \%$ & $17.0 \%$ & $100.0 \%$ \\
\hline Pasighat & 65 & 12 & 23 & 100 \\
& $65.0 \%$ & $12.0 \%$ & $23.0 \%$ & $100.0 \%$ \\
\hline Ruksin & 78 & 12 & 10 & 100 \\
& $78.0 \%$ & $12.0 \%$ & $10.0 \%$ & $100.0 \%$ \\
\hline Total & $\mathbf{2 0 7}$ & $\mathbf{4 3}$ & $\mathbf{5 0}$ & $\mathbf{3 0 0}$ \\
& $\mathbf{6 9 . 0 \%}$ & $\mathbf{1 4 . 3 \%}$ & $\mathbf{1 6 . 7 \%}$ & $\mathbf{1 0 0 . 0 \%}$ \\
\hline
\end{tabular}

Source: Field Survey, 2017-18

It is revealed from Table 3 that, out of total the respondents, 69 per cent think that Panchayati Raj Institutions encourage popular participation of villagers and 14.3 per cent think that Panchayati Raj Institution does not encourage popular participation of villagers.
Also, 16.7 per cent has no answer to it. People's participation in local level planning means participative development. In its ideal form, local planning implies entrusting to the local people and their institutions all duties and responsibilities of local planning and 
development, with the government reserving to itself only the functions of guidance, supervision and higher planning. In fact, the local level planning process is of working with the local people, most directly affected by facilities and programmes, so the plan should be more responsive to local needs; reflects more accurately local perceptions; produces a sense of local ownership and responsibility; builds on and reinforces the fabric of the community and its internal structure; and supports the evolution of a continuing ongoing structure of local administration by involvement of people. The above aspects are important, because the local people having worked to make a project happen, and having involvement which makes them a part of development process, and create an attachment towards the panchayats. So, they would show their eagerness and willingness into by participating in various activities of panchayats like administration, maintenance and planning for the development. Elected members of the Panchayat Samitis and local people, needs to get directly involved in implementation of the development programmes and prepare a shelf of need based projects which, after sanction at the block and district level, to be executed by them with the funds made available to them. In short, people should actively participate in the development process directly and through their elected representatives. So, strategy for rural development must involve the people themselves and their institutions at all levels. The need for revitalising Panchayati Raj Institutions has, therefore been recognised as an instrument for participative planning and implementation of various development programmes at grass root level. As discussed earlier in this chapter participation has become necessary not only for better planning of various poverty alleviation programmes but, more importantly, for minimising leakages in their implementation so that the benefits of these programmes reach the poor. The absence of panchayats involving local participation in decision making with the government and creating conditions for their functioning, will be regarded as the most important shortcoming.

Table-4: Concern of villagers for planning a scheme

\begin{tabular}{|l|l|l|l|l|}
\hline \multirow{2}{*}{$\begin{array}{l}\text { Panchayat } \\
\text { Division }\end{array}$} & \multicolumn{3}{|l|}{ Do PRIs take into concern of villagers for planning a scheme } & \multirow{2}{*}{ Total } \\
\cline { 2 - 4 } Mebo & Yes & No & Don't Response & \\
\hline Pasighat & $27(64.0 \%)$ & $22(22.0 \%)$ & $14(14.0 \%)$ & $100(100.0 \%)$ \\
\hline Ruksin & $71(71.0 \%)$ & $34(34.0 \%)$ & $39(39.0 \%)$ & $100(100.0 \%)$ \\
\hline Total & $\mathbf{1 6 2}(\mathbf{5 4 . 0 \%})$ & $29(29.0 \%)$ & $0(0.0 \%)$ & $100(100.0 \%)$ \\
\hline
\end{tabular}

Source: Field Survey, 2017-18

Planning is the process of thinking about and organising the activities required to achieve a desired goal. In India much importance has been given on rural development planning for improvement of quality of life by enhancing socio economic betterment of rural areas. Especially, in case of panchayats they are directed to involve locals in the participatory process, but there are few instances where they fail in involving the locals. The above table tries to understand the role of panchayats in involving the locals in planning of schemes.

It is uncovers from Table-4 that, 54.0 per cent of respondents opined that local bodies take the concern of villagers, while 28.3 per cent thinks panchayats do not take concern of villagers while planning a scheme for the area and 17.7 per cent don't have any idea. The reason of not taking the concern of villagers may be because of lack of technical knowhow, involvement of party politics or may be the weakness of the panchayats themselves. But whatever may be the reason, poverty alleviation through participative approach by the panchayats is the need of the hour. So, poverty alleviation process needs a paradigm shift from the complex technical content of programme methods, party politics, public leaders and other governmental officials. As sometimes government policies may have unintended negative consequences for the needful poor, but it's the local panchayats which can transmit the government policies successfully at grassroots level. Hence, the local bodies need to be well attended by the government.

Table-5: Consideration of villagers for proposal of schemes

\begin{tabular}{|l|l|l|l|l|}
\hline \multirow{2}{*}{$\begin{array}{l}\text { Panchayat } \\
\text { Division }\end{array}$} & \multicolumn{2}{|l|}{ Do PRIs consider proposal put forward by villagers for schemes } & \multirow{2}{*}{ Total } \\
\cline { 2 - 5 } Mebo & Yes & No & Don't Know & \\
& 48 & 23 & 27 & 98 \\
& $49.0 \%$ & $23.5 \%$ & $27.6 \%$ & $100.0 \%$ \\
\hline Pasighat & 27 & 30 & 43 & 100 \\
& $27.0 \%$ & $30.0 \%$ & $43.0 \%$ & $100.0 \%$ \\
\hline Ruksin & 71 & 25 & 4 & 100 \\
& $71.0 \%$ & $25.0 \%$ & $4.0 \%$ & $100.0 \%$ \\
\hline Total & $\mathbf{1 4 6}$ & $\mathbf{7 8}$ & $\mathbf{7 4}$ & $\mathbf{2 9 8}$ \\
& $\mathbf{4 9 . 0 \%}$ & $\mathbf{2 6 . 2 \%}$ & $\mathbf{2 4 . 8 \%}$ & $\mathbf{1 0 0 . 0 \%}$ \\
\hline
\end{tabular}

Source: Field Survey, 2017-18 
It is observed from Table 5 that, out of the total respondents, 49.0 per cent think that Panchayat members consider the proposals put forward by villagers regarding the implementation of schemes while 26.2 per cent thinks Panchayat does not take into consideration the proposals put forward by villagers and 24.8 per cent do not have any idea regarding this. Block wise analysis shows that, both Mebo and Pasighat have 49.0 and 27.0 per cent respondents that think Panchayat members considers the proposals put forward by villagers regarding the implementation of schemes and in Ruksin 70 per cent think that Panchayat members takes the consultation of the villagers. It is inferred from
Table- 5 that, an integrated approach is the need of the hour to include change in sharing of power between party leaders, panchayat officials, panchayat bodies and public, with regards to which policies have to be adapted and to share decision making in development arrangements. It is also more important to involve rather than only initiate change to support decision making and determining new structural arrangements. Participatory roles by locals should be supported and encourage in decision and implementations making with individual households to enhance suggestions and support from grass root level rather than only issuing directives.

Table-6: Voting Considerations

\begin{tabular}{|c|c|c|c|c|c|}
\hline \multirow{2}{*}{$\begin{array}{l}\text { Panchayat } \\
\text { Division }\end{array}$} & \multicolumn{4}{|c|}{ Do you vote in considerations of issues concerning } & \multirow[t]{2}{*}{ Total } \\
\hline & Local area & State & National & Don't know & \\
\hline Mebo & $\begin{array}{l}81 \\
81.0 \%\end{array}$ & $\begin{array}{l}10 \\
10.0 \%\end{array}$ & $\begin{array}{l}7 \\
7.0 \%\end{array}$ & $\begin{array}{l}2 \\
2.0 \%\end{array}$ & $\begin{array}{l}100 \\
100.0 \%\end{array}$ \\
\hline Pasighat & $\begin{array}{l}58 \\
58.0 \%\end{array}$ & $\begin{array}{l}17 \\
17.0 \%\end{array}$ & $\begin{array}{l}25 \\
25.0 \%\end{array}$ & $\begin{array}{l}0 \\
0.0 \%\end{array}$ & $\begin{array}{l}100 \\
100.0 \%\end{array}$ \\
\hline Ruksin & $\begin{array}{l}79 \\
79.0 \%\end{array}$ & $\begin{array}{l}13 \\
13.0 \%\end{array}$ & $\begin{array}{l}8 \\
8.0 \%\end{array}$ & $\begin{array}{l}0 \\
0.0 \%\end{array}$ & $\begin{array}{l}100 \\
100.0 \%\end{array}$ \\
\hline Total & $\begin{array}{l}218 \\
72.7 \%\end{array}$ & $\begin{array}{l}40 \\
13.3 \%\end{array}$ & $\begin{array}{l}40 \\
13.3 \%\end{array}$ & $\begin{array}{l}2 \\
0.7 \%\end{array}$ & $\begin{array}{l}300 \\
100.0 \%\end{array}$ \\
\hline
\end{tabular}

It is unveiled from Table- 6 that, out of total respondents, 72.7 votes in consideration of issues concerning local area, 13.3 per cent vote in consideration of issues concerning state, again 13.3 per cent vote in consideration of issues concerning nation and 0.7 per cent have no any consideration of issues in voting. Thus, local issue is the most important considerations for voting. Just involvement of people in universal franchise and peoples' participation in elections do not serve the purpose as people are ignorant of franchise rights and voting considerations till recently. In recent years, there has been a growing awareness of grassroots people in many places, people started the agenda of no development no vote. As tribal state like Arunachal is burdened with the enormous problems of economic development. Hence, people of this region need to be cautious in voting considerations.

It is observed from Table-7 that, out of the total respondents, 70.3 per cent respondents attend Panchayat meetings and 29.7 per cent respondents do not attend Panchayat meetings. Block wise analysis shows that, both Ruksin and Pasighat have 63.0 and 65.0 per cent respondents that attend Panchayat meetings and Mebo has 83 per cent respondents that attend Panchayat meetings.

Table-7: Attend Panchayat Meetings

\begin{tabular}{|l|l|l|l|}
\hline \multirow{2}{*}{$\begin{array}{l}\text { Panchayat } \\
\text { Division }\end{array}$} & \multicolumn{2}{|l|}{ Do you attend Panchayat Meetings } & \multirow{2}{*}{ Total } \\
\cline { 2 - 3 } & Yes & No & \\
\hline Mebo & 83 & 17 & 100 \\
& $83.0 \%$ & $17.0 \%$ & $100.0 \%$ \\
\hline Pasighat & 65 & 35 & 100 \\
& $65.0 \%$ & $35.0 \%$ & $100.0 \%$ \\
\hline Ruksin & 63 & 37 & 100 \\
& $63.0 \%$ & $37.0 \%$ & $100.0 \%$ \\
\hline Total & $\mathbf{2 1 1}$ & $\mathbf{8 9}$ & $\mathbf{3 0 0}$ \\
& $\mathbf{7 0 . 3 \%}$ & $\mathbf{2 9 . 7 \%}$ & $\mathbf{1 0 0 . 0 \%}$ \\
\hline
\end{tabular}

Source: Field Survey, 2017-18

So far, the Panchayat Samiti has succeeded in bringing about democratic structural change and, to some extent, in activating and making the people involved in local self-government. The success and failure of the panchayat Samiti in involving public depends upon the guidance it receives from the higher authority of Panchayati Raj and the higher public 
bureaucracy, technical and non-technical, and the regular and adequate flow of financial resources [7].

\section{CONCLUSION}

Involvement of the villagers in Panchayati Raj activities, consultation of the villagers in planning a scheme, consideration of the villagers for proposal of schemes and participation of the villagers in Panchayat Meetings of East Siang District have been analysed during the study. The study found a contradiction of view point with regard to participation of villagers. Quite a good number of respondents hold the view that they have not actively participated because they were not encouraged by the panchayat members. On the other hand, panchayat members consider that they had never been an obstacle to people's participation rather, they encourage them to participate in the developmental programmes initiated by them. However, the lack of participation of people in the developmental programmes is not exclusively the responsibility of the Panchayati Raj Representatives, though to some extent requires the encouragement of the panchayat representatives and office bearers. The initiative of common villagers in their individual or collective capacity is equally required for the effective implementation of any developmental programmes. Hence, awareness campaign such as workshop, demonstration, seminar, symposium, etc. are to be conducted in the remote rural areas to make full participation of the people in the developmental programmes.

With regards to the developmental works taken up by panchayats, quite a good numbers of respondents opined that most of the works meant for the rural poor are not reaching the targeted group and are not implemented in accordance with the guidelines of the schemes. With regards to implementation of schemes relating to animal husbandry and fisheries, agriculture and minor irrigation management, drinking water and sanitation management, etc. the villagers expressed their dissatisfaction. Further, regarding the formulation and implementation of village plan, it is revealed that the panchayat members and local officials do not consult the villagers.

\section{REFERENCE}

1. Bhalerao, C. N. (1964). Some Social, Political and Administrative Consequences of Panchayati Raj, Asian Survey, Vol. No. 4, PP. 804-811. University of California, Press Stable URL: http://www.jstor.org/stable/3023417 Accessed: 0608-2015 08:31.

2. Dubey, S. (2005). Dynamics of Tribal Polity and Panchayati Raj in Arunachal Pradesh, New Delhi, Premiere Publishing House, p. 7.1

3. Gyati, A. (2012). Democratic Decentralisation in a Frontier Tribe, The Apa Taniis, Itanagar, Himalayan Publishers, p.65-66.

4. Malini, N. (2001). Making the Gram Sabha Work, Economic and Political Weekly, Vol. 36, No. 33 (Aug. 18-24, 2001), pp. 3114-3117 Published by: Economic and Political Weekly Stable URL: http://www.jstor.org/stable/4410988 Accessed: 0608-2015 08:36

5. Narayan, S. (1981). Tribals and their Participation in Panchayati Raj: A Case Study of Ranchi Indian Anthropologist, Vol. 11, No. 2 (December), Indian Anthropological Association, http://www.jstor.org/stable/41919420, 06-08-2015 08:30, pp. 87-100

6. Rao, C. H. (1989). Decentralised planning: an overview of experience and prospects. Economic and Political Weekly, 411-416.

7. Swain, P. C., \& Swain, P. C. (2008). Panchayati Raj, New Delhi, A.P.H. Publishing Corporation, p. 60-61.

Cite This Article: Kamin Modi et al (2021). Participation of Public in Panchayati Raj Institutions of East Siang District, Arunachal Pradesh. East African Scholars J Edu Humanit Lit, 4(3), 114-119. 